R. Soc. Lond. B. 353, 1841-1849 (1998)

6. Steriade, M. Synchronized activities of coupled oscillators in the cerebral cortex and thalamus at different levels of vigilance. Cerebral Cortex 7, 583-604 (1997).

7. Gray, C.M. The temporal correlation hypothesis of visual feature integration: Still alive and well. Neuron 24, 31-47 (1999).

8. Shadlen, M.N. \& Movshon, I.A. Synchrony unbound: A critical evaluation of the temporal binding hypothesis. Neuron 24, 67-77 (1999).

9. Steriade, M., McCormick, D.A. \& Sejnowski, T.J. Thalamocortical oscillations in the sleeping and aroused brain. Science 262, 679-685 (1993)

10. Steriade, M, Jones, E.G. \& McCormick, D.A., Thalamus vol. I. Organization and Function (Elsevier
New York, 1997).

11. McCormick, D.A. Spontaneous activity: Signal or noise? Science 285, 541-543 (1999).

12. Danober, L., Deransart, C., Depaulis, A., Vergnes, M. \& Marescaux, C. Pathophysiological mechanisms of genetic absence epilepsy in the rat. Prog. Neurobiol. 55, 27-57 (1998).

13. Raeva, S., Vainberg, N. \& Dubinin, V. Analysis of spontaneous activity patterns of human thalamic ventrolateral neurons and their modifications due to functional brain changes. Neuroscience $\mathbf{8 8}$, 365-376 (1999).

14. Lang, A.E. \& Lozano, A.M. Parkinson's disease. N. Engl. J. Med. 16, 1130-1143 (1998).

15. Lenz, F.A. \& Dougherty, P.M. in Thalamus Vol. II Experimental and Clinical Aspects (eds. Steriade, M.,
Jones, E.G. \& McCormick, D.A.) 617-651 (Elsevier, New York, 1997).

16. Llinás, R.R. The intrinsic electrophysiological properties of mammalian neurons: insights into central nervous system function. Science 242, 1654-1664 (1988).

\section{Section of Neurobiology}

Yale University School of Medicine

333 Cedar Street

New Haven, CT 06510

Email: david.mccormick@yale.edu

www.mccormicklab.org

\title{
Who's that lady?
}

\begin{abstract}
An analysis of scientific and social literature suggests that army bases located in France and the UK may be responsible for the worldwide distribution of the 'Spanish Lady' influenza pandemic of 1918.
\end{abstract}

$1 \mathrm{HE}$ 'SPANISH' INFLUENZA pandemic of 1918-1919 killed over 40 million people world-wide ${ }^{1}$. But how could a virus spread throughout the world so rapidly? It seems inconceivable that a virus, even influenza, could be dispersed over such great distances in such a short time without an earlier 'seeding' of the virus. In this context, two rediscovered clinical and bacteriological descriptions are relevant. The first ${ }^{2}$ reports a 1916 outbreak of 'purulent bronchitis' at an unidentified army base in France, whereas the second $^{3}$ records another 1917 outbreak in the UK, at Aldershot Barracks.

We have reviewed the scientific and social literature published before 1918 for any indication of earlier outbreaks. This material includes medical war records at the Public Record Office (Kew), the British Library and the Imperial War Museum (all based in London, UK). We were prompted to undertake this search by a simple observation on the timings of deaths of the nine influenza victims who constitute, at present, the direct sources of clinical specimens and influenza A genes from that era. These victims were located in Fort Jackson (soldier; US) ${ }^{4}$, Camp Upton (soldier; US) ${ }^{5}$, Brevig Mission (Inuit woman; Alaska, US) ${ }^{5}$ and Longyearbyen (six Norwegian coal miners, Spitsbergen) ${ }^{6}$. Despite their wide geographical dispersion around the Northern Hemisphere, the dates of death of these victims are within a very narrow time period: late September-November 1918. Furthermore, influenza deaths at the same time were re-

\section{J.S. OXFORD ${ }^{1}$, A. SEFTON ${ }^{1}$, R. JACKSON ${ }^{1}$, N.P.A.S JOHNSON ${ }^{2} \&$ R.S. DANIELS ${ }^{3}$}

ported in regions as far apart as South Africa $^{7}$, India ${ }^{8}$ and Indonesia ${ }^{9}$. In relation to the 'seeding' of the 'Great Influenza Pandemic of 1918', mortality figures for bronchopneumonia increased in the USA during the entire period of 1914-1918 (ref. 10). A similar review of records of bron-

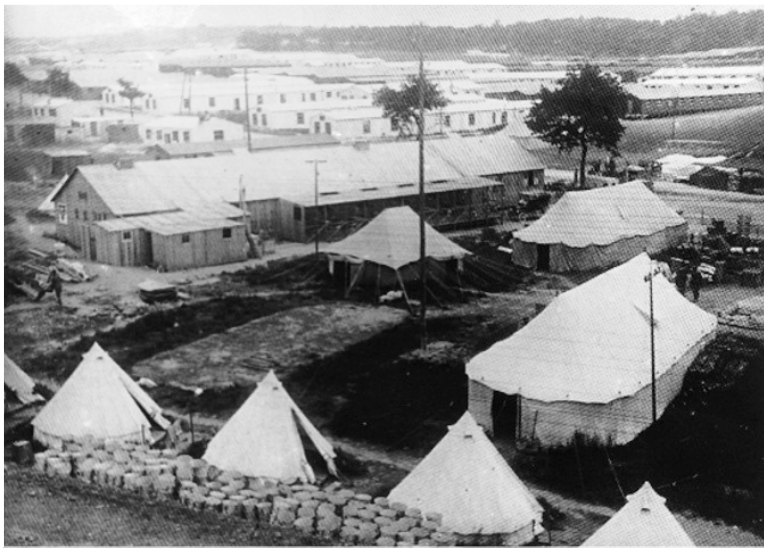

France, 1918. General army hospitals at Etaples en route to Carniers.

high temperature and cough at a time when the recognized influenza was present. Despite the war and censorship at the time, we now have strong indications that the previously unidentified base hospital was at Etaples in Northern France, where one of the co-authors, T.H.G. Shore, was working. It was a large camp, with 100,000 soldier inhabitants at any time and many hospitals (Fig. 2). This 'outbreak' was further characterized by cyanosis and extremely high mortality. Clinical examination showed, in most cases, signs of bronchopneumonia, and histology showed an acute purulent bronchitis. Our clinical microbiological review of the paper ranks the description as classic influenza being particularly similar to the extensive literature of deaths in 1918-1919 (ref. 12).

In the earlier literature, influenza was often described clinically as 'epidemic catarrhal fever $^{\prime 13}$. Essentially identical epidemic outbreaks of purulent bronchitis with bronchopneumonia, with cases showing a peculiar dusky heliotype cyanosis and mortality rates of $25-50 \%$, were

chopneumonia deaths at the Royal London Hospital shows a peak in 1918 but substantial numbers between 1914 and 1917 (Fig. 1) whereas, on a national scale, there is clear evidence of spread of a virus from May 1918 (ref. 11) that showed enhanced lethality from June 1918 onwards ${ }^{12}$.

Hammond et al. ${ }^{2}$ reported that in 1916 , large numbers of soldiers were admitted to a French base hospital, reportedly suffering from an acute respiratory infection, described in Aldershot barracks in March 1917(ref. 3). Furthermore, Abercrombie ${ }^{14}$ recorded: "Early in 1917 I had under my care in France a large number of (young) soldiers suffering from a grave form of purulent bronchitis proceeding in some cases to bronchopneumonia. The cases exhibited dyspanea, a heliotrope cyanosis, pyrexia and a high mortality".

Shortridge ${ }^{15}$ argues cogently that influenza A (H1N1) may have spread in China for 70 of the last 110 years, and that 


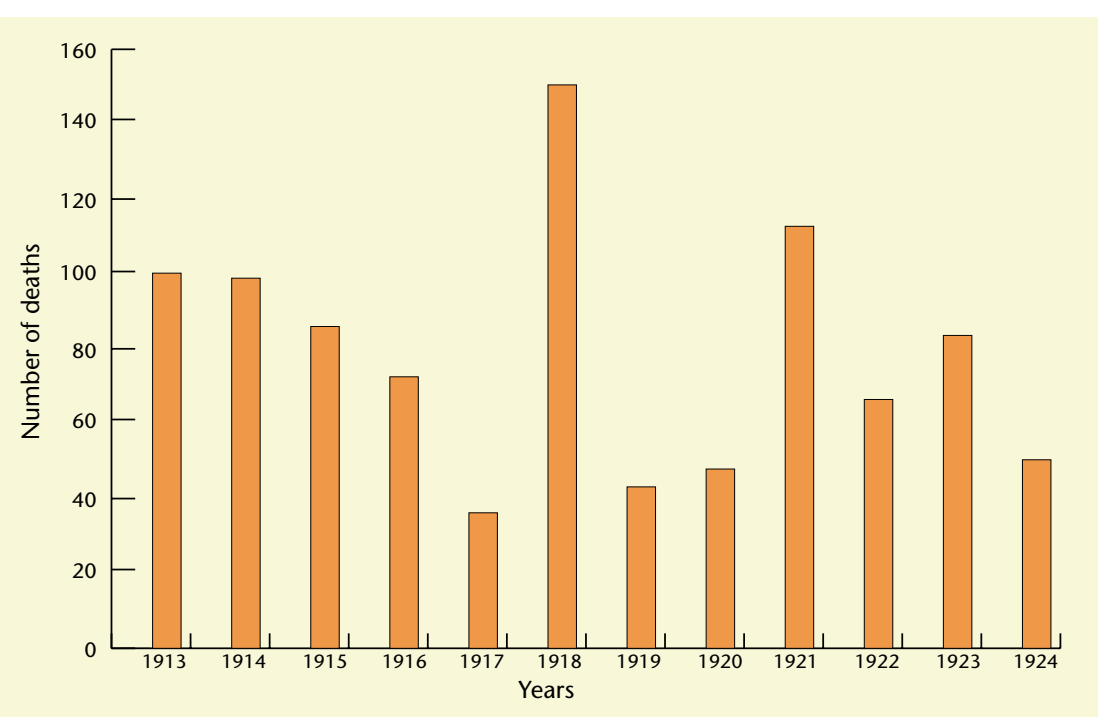

Fig. 1 Deaths from bronchopneumonia at The London Hospital 1913-1924.

the description 'Spanish Influenza' for the 'Great Influenza Pandemic of 1918' should be dropped, as the virus could by implication have Chinese origin and be recognized as the 'Chinese Lady'. However, despite the employment of many Chinese laborers at Etaples, the re-evaluation we have now done would suggest caution in identifying Hong Kong, China or the USA as the original epicenter of the pandemic. To our knowledge, we have located the earliest ${ }^{2,3}$ precise clinical and pathological descriptions matching those of the 'Great Influenza Pandemic of 1918' where locations have been identified. We propose that the confined outbreaks of purulent bronchitis with high mortality occurring in Europe in 1916 were typical of influenza as described in 1918 and subsequently ${ }^{12}$. Clearly, we must bear in mind Shortridge's arguments of a possible role of China as the epicentre for the emergence of new influenza A epidemics. However, although there is general agreement that the name 'Spanish Influenza' is inappropriate, we now conclude that the virus could have been designated A/Etaples/1/1916 or A/Aldershot/1/1917 turning, in colloquial terms, the 'Spanish Lady' of 1918 into the 'French Lady' or 'English Lady' of 1916 or 1917.

The question is not purely academic, as a new pandemic influenza $A$ virus is anticipated and the World Health Organization, along with the governments of several countries, have published influenza pandemic plans ${ }^{16}$. Moreover, the direct spread of avian H5 to humans in Hong Kong in 1997 (ref. 17) and more recently, evidence of direct transmission of avian $\mathrm{H} 9$ to humans ${ }^{18,19}$ have increased concerns about future pandemics. The initial analyses of influenza hemagglutinin (HA) genes from the two American soldiers and the Inuit lady have failed to detect nucleotide changes encoding amino-acid substitutions which have been associated with enhanced virulence ${ }^{5}$. However, virulence determinants could be present in either non-structural protein 1 (NS1) (ref. 20), or neuraminidase ${ }^{21}$, or nucleoprotein $^{22}$ or be scattered throughout the genome.

It is also possible that the severe 1918-1919 pandemic outbreak was a singular event triggered partly by a virus of enhanced virulence but helped greatly by mass movement of young persons after the armistice in November 1918. This resulted in movement of people around the globe, with demobilized troops returning from the battlefields of World War One and even civilians returning from gatherings in celebration of the cessation of war $^{23}$. This would explain why the earlier influenza outbreaks of 1916-1917, although causing a high mortality locally, did not spread widely in the world community. Finally, the description of these early outbreaks in France and England concur with the genetic analysis of the 1918 virus, which places the origin of the virus around 1915 (ref. 5).

1. The Spanish Flu 1918-1998: Reflections on the Influenza Pandemic of 1918 after 80 years. (Cape Town, 12-15 September 1998) (in the press).

2. Hammond, J.A.B., Rolland, W. \& Shore, T.H.G. Purulent bronchitis: A study of cases occurring amongst the British troops at a base in France. Lancet ii, 41-45 (1917).

3. Abrahams, A., Hallows, N.F., Eyre, J.W.H., \& French, $\mathrm{H}$. Purulent bronchitis: its influenza and pneumococcal bacteriology. Lancet ii, 377-380 (1917).

4. Taubenberger, J.K., Reid, A.H., Krafft, A.E., Bijwaard,
K.E., \& Fanning, T.G. Initial genetic characterisation of the 1918 "Spanish" influenza virus. Science 275, 1793-1796 (1997).

5. Reid, A.H., Fanning, T.G., Hultin, J.V. \& Taubenberger, J.K. Origin and evolution of the 1918 "Spanish" influenza hemagglutinin gene. Proc. Natl Acad. Sci. USA 96, 1651-1656 (1999).

6. Davis, J.L. et al. Application of ground penetrating radar in permafrost to locate the bodies of seven victims of the 1918 "Spanish Flu". Journal of Forensic Science (in the press).

7. Phillips, H. 'Black October': the impact of the Spanish Influenza epidemic of 1918 or South Africa, in Archives Year Book for South African History (The Government Printer, Pretoria, 1990).

8. Mills, I.D. The 1918-1919 Influenza Pandemic-The Indian Experience. Indian Economic and Social History Review 23 (1986)

9. Brown, C. in Death and Disease in Southeast Asia: Explorations in Social, Medical and Demographic History (ed. Norman G. Owen) 235-256. (Oxford University Press, Oxford, 1987).

10. Van Tam J.S.N. in Textbook of Influenza (eds. Nicholson, K.G., Webster, R.G. \& Hay A.J.) 181-206 (Blackwell Publishers, Oxford, UK, 1998).

11. Registrar-General, in Supplement to the Eighty-First Annual Report of the Registrar-General. Report on the mortality from influenza in England and Wales during the epidemic of 1918-1919. (HMSO, London, 1920).

12. Opie E.L., Blake F.G., Small J.C., \& Rivers T.M. in Epidemic Respiratory Disease: The Pneumonias and Other Infections of the Respiratory Tract Accompanying Influenza and Measles (ed. Kimpton, H.) 402 (London, 1921)

13. Thompson, T. in Annals of Influenza or Epidemic Catarrhal Fever in Great Britain from 1510 to 1837. (Sydenham Society, London, 1852).

14. Macpherson, W.G., Herringham, W.P., Elliott, T.R. \& Balfour, A. in History of the Great War (eds. Macpherson, W.G., Herringham, W.P., Elliott, T.R. \& Balfour, A.) 174-211 (HMSO, London, 1920).

15. Shortridge, K.F. The 1918 'Spanish' Flu: pearls from swine? Nature Med. 5, 384-385 (1999).

16. Influenza Pandemic Plan, in The Role of WHO and guidelines for National and Regional Planning. (World Health Organization, Geneva, Switzerland, 1999).

17. Yuen, K.Y. et al. Clinical features and rapid viral diagnosis of human disease associated with avian influenza A H5N1 virus. Lancet 351, 467-471 (1998).

18. Guan, Y., Shortridge, K.F., Krauss, S., \& Webster, R.G. Molecular characterization of H9N2 influenza viruses: were they the donors of "internal" genes of H5N1 viruses in Hong Kong? Proc. Natl. Acad. Sci. USA 96, 9363-9369 (1997).

19. Peiris $M$. et al. Human infection with influenza H9N2. Lancet 354, 916-917 (1999).

20. Garcia-Sastre, A. et al. Influenza A virus lacking the NS1 gene replicates in interferon-deficient systems. Virology 252, 324-330 (1998).

21. Goto, H. \& Kawaoka Y. A novel mechanism for the acquisition of virulence by a human influenza $A$ virus. Proc. Natl. Acad. Sci. USA 95, 10224-10228 (1998).

22. Scholtissek C., Koennecke I. \& Rott R. Host range recombinants of Fowl Plague (influenza A) virus. Virology 91, 79-85 (1978).

23. Johnson N.P.A.S. The Spanish Flu 1918-1998: Reflections on the Influenza Pandemic of 1918 after 80 years. (Cape Town, 12-15 September 1998) (in the press).

\section{${ }^{1}$ Department of Medical Microbiology \&} Retroscreen Virology

St. Bartholomew's and

The Royal London School

of Medicine and Dentistry E1 2AD

Internet: www.retroscreen.com

${ }^{2}$ Department of Geography

University of Cambridge, CB2 3EN

${ }^{3}$ Virology Division, NIMR, London NW7 1AA 